\title{
KONTEKSTUALISASI PEMIKIRAN WARIS ABDULLAH SAEED DALAM HUKUM KEWARISAN DI INDONESIA
}

\author{
Suqiyah Musafa'ah \\ Universitas Islam Negeri Sunan Ampel Surabaya, Indonesia \\ E-mail: uqiefais@gmail.com
}

\begin{abstract}
This article seeks to discuss the issue of inheritance in Indonesia and the solution offered through studying the Quranic verses of inheritance according to Abdullah Saeed. Saeed's methodological approach is used as a tool of analysis to reconstruct the law of inheritance in Indonesia. On the one hand, Saeed's theory of 'value hierarchy' is formulated in order to maintain the principle of Islam's universality. On the other hand, this theory is applied in order for Islam to be valid for every time and place (sâliḥ li kull zamân wa makân). Saeed's theory of 'value hierarchy' consists of among others obligatory values, fundamental values, protectional values, implementational values, and instructional values. Based on Saeed's theory of value hierarchy, the division of inheritance based of customary law (adat) called dumdum kupat (the portion of inheritance for son and that for daughter is the same) is valid and can be applied.
\end{abstract}

Keywords: Inheritance; theory of value hierarchy; universality.

\section{Pendahuluan}

Hukum kewarisan di Indonesia sejak dahulu sampai saat ini masih beragam bentuknya, masing-masing golongan penduduk patuh pada aturan-aturan hukum yang berlaku sesuai dengan ketentuan pasal 163 I.S. Jo. Pasal 131 I.S. ${ }^{1}$ Berdasarkan peraturan undang-undang R.I. UU No. 62 / 1958 dan Keppers No. 240 / 1957 pembagian golongan penduduk seperti di atas telah dihapuskan.

Hukum waris dapat dilihat di dalam Hukum Kewarisam Islam, Hukum Adat, dan Kitab Undang-Undang Hukum Perdata (BW). Ketiga sistem hukum ini memiliki karakteristik dan ciri khas masing-

\footnotetext{
${ }^{1}$ Indische Staatsregeling, Staatsblad 1925 No. 415, Jo. 577.
} 
masing yang mengakibatkan terjadinya distingsi antara yang satu dengan lainnya. Namun demikian apabila berbicara persoalan hukum waris, maka tidak terlepas dari tiga unsur pokok, yaitu: adanya harta peninggalan, pewaris, dan ahli waris.

Bagi golongan masyarakat Muslim diberlakukan hukum kewarisan Islam yang tertuang dalam Kompilasi Hukum Islam (KHI), baik mengenai tata cara pembagian harta pusaka, besarnya bagian antara laki-laki daripada anak perempuan, dan anak angkat. Lembaga peradilan berhak memeriksa dan memutuskan apabila terjadi perselisihan di antara para ahli waris dan lain sebagainya.

Untuk masyarakat non-Muslim, mereka tunduk kepada hukum urf masing-masing dan dipengaruhi oleh unsur-unsur agama dan kepercayaan. Begitu juga masyarakat Eropa, di mana mekanisme hukum waris sepenuhnya diserahkan kepada hukum perdata Eropa (kitab undang-undang hukum perdata).

Dari sekian varian perbedaan hukum waris, belum ada keseragaman tentang pengertian dan makna hukum waris yang dipedomani dan berlaku untuk seluruh wilayah Republik Indonesia.

Hukum kewarisan Islam menurut ilmu farâid, dalam istilah bahasa, adalah takdir (qadar) atau ketentuan, dan dalam istilah shara adalah bagian-bagian yang ditentukan bagi ahli waris. Dengan demikian farâid adalah bagian ahli waris yang telah ditentukan besar kecil pembagian oleh shara ${ }^{2}$ Sedangkan hukum kewarisan ditinjau dari hukum adat adalah aturan-aturan mengenai cara bagaimana peralihan dari harta kekayaan yang berwujud dan tidak berwujud dari generasi kepada generasi selanjutnya, ${ }^{3}$ atau peraturan-peraturan yang mengatur proses meneruskan serta mengoper barang-barang yang tidak berwujud benda (immateriele goederen) dari suatu angkatan manusia (generatio) kepada turunannya. ${ }^{4}$

Jadi hukum waris adat sesungguhnya adalah hukum penerusan harta kekayaan dari suatu generasi kepada keturunannya. Cara penerusan dan peralihana harta kekayaan ini dapat berlaku sejak pewaris masih hidup atau setelah meninggal dunia. Hal inilah yang membedakannya dengan hukum waris Barat (KUH Perdata), juga hukum kewarisan Islam. Tata cara pengalihan atau penerusan harta kekayaan pewaris kepada ahli waris menurut hukum adat dapat terjadi

\footnotetext{
${ }^{2}$ Fatchur Rahman, Ilmu Waris (Bandung: Penerbit al-Maarif, Cet. Ke-2, 1982), 32.

${ }^{3}$ Ahmad Azhar Basyir, Hukum W aris Islam (Yogyakarta: UII Press, 2001), 119.

${ }^{4}$ Ibid.
} 
penunjukan, penyerahan kekuasaan atau penyerahan pemilikan atas bendanya oleh pewaris kepada ahli waris.

Prinsip atau asas umum hukum waris adat di antaranya adalah sebagai berikut: jika kewarisan tidak dapat dilaksanakan secara menurun, maka kewarisan ini dilakukan secara ke atas atau ke samping. Artinya, yang menjadi ahli waris pertama adalah anak lakilaki atau perempuan dan keturunan mereka. Bila kelompok pertama tersebut tidak ada, maka yang menjadi ahli waris adalah ayah, ibu, kakek, nenek, dan seterusnya. Kalau kelompok kedua ini juga tidak ada, maka yang mewarisi adalah saudara-saudara si peninggal harta dan keturunan mereka yaitu keluarga sedarah menurut garis ke samping, dengan pengertian bahwa keluarga yang terdekat mengecualikan keluarga yang jauh.

Menurut hukum adat tidak selalu harta peninggalan seseorang itu langsung dibagi di antara para ahli waris, karena terkadang pembagiannya ditangguhkan atau bahkan ada yang tidak dibagikan, sebab harta tersebut merupakan satu kesatuan yang tidak dapat dibagi untuk selamanya. Pun hukum adat mengenal prinsip penggantian tempat (Plaatsvervulling). Artinya, seorang anak sebagai ahli waris dari ayahnya, maka tempatnya dapat digantikan oleh anak-anaknya bila ia meninggal dunia (cucu yang mewariskan), dan bagian cucu ini adalah sama dengan yang akan diperoleh ayahnya sebagai bagian warisan yang diterimanya. $^{5}$

Hukum adat juga mengenal adanya lembaga pengangkatan anak (adopsi), di mana hak dan kedudukan juga bisa seperti anak sendiri (kandung). ${ }^{6}$ Hukum adat tidak mengenal cara pembagian dengan perhitungan matematika (angka), tetapi selalu didasarkan atau atas pertimbangan wujud benda dan kebutuhan ahli waris yang bersangkutan. Jadi walaupun hukum waris adat mengenal asas kesamaan hak, tidak berarti setiap ahli waris akan mendapat bagian warisan dalam jumlah yang sama, dengan nilai harga yang sama atau menurut banyaknya bagian yang sudah ditentukan.

Tata cara pembagian waris adat itu ada dua opsi, antara lain: dengan cara segendong sepikul. Artinya, bagian anak lelaki dua kali lipat bagian anak perempuan atau dengan cara dum-dum kupat, di mana bagian anak lelaki dan bagian anak perempuan sama. Namun kebanyakan yang berlaku adalah yang pembagian berimbang sama di

\footnotetext{
${ }^{5}$ Ibid., 126.

${ }^{6}$ Ibid., 149.
} 
antara semua anak. Demikian corak dan sifat-sifat yang khas kewarisan adat di Indonesia yang berbeda dengan hukum Islam. Semua ini merujuk pada alam pluralitas pikiran bangsa Indonesia yang didasarkan pada kehidupan komunal dan bersifat tolong-menolong untuk merealisir kehidupan yang rukun, selaras, dan damai.

Kitab Undang-undang hukum perdata (Burgerlijk Wetboek) juga memberikan batasan tentang pengertian dan definisi hukum waris sebagai suatu pedoman kewarisan, sebagaimana tertuang dalam Pasal 830 BW: "Kewarisan hanya berlangsung karena kematian". Pasal 832 BW mengatakan: "Menurut Undang-undang yang berhak untuk menjadi ahli waris adalah keluarga sedarah, baik sah maupun tidak sah (menurut agama), dan si suami atau istri yang hidup terlama. Jika keluarga sedarah maupun (istri) yang hidup terlama di antara suami istri tidak ada, maka segala harta peninggalan yang meninggal menjadi milik negara, di mana negara juga wajib menanggung segala hutangnya disesuaikan dengan harta yang diwariskan. ${ }^{8}$

Hukum waris Barat yang dimaksud adalah sebagaimana diatur dalam KUH Perdata (BW) yang menganut sistem individual, di mana harta peninggalan pewaris yang telah wafat diadakan pembagian. Ketentuan aturan ini berlaku kepada warga negara Indonesia keturunan asing seperti Eropa, Cina, bahkan keturunan Arab dan lainnya yang tidak lagi berpegang teguh pada ajaran agamanya. ${ }^{9}$ Ini berarti hukum waris Barat menganut aturan bahwa saat pewaris wafat, harta warisan langsung dibagikan kepada ahli waris. Setiap ahli waris dapat menuntut agar harta peninggalan (pusaka) yang belum dibagi segera dibagikan, walaupun ada perjanjian yang bertentangan dengan itu. Kemungkinan untuk menahan atau menangguhkan pembagian harta warisan itu disebabkan satu dan lain hal dapat berlaku atas kesepakatan para ahli waris, tetapi tidak boleh lewat waktu lima tahun kecuali dalam keadaan luar biasa waktu lima tahun dapat diperpanjang dengan suatu perpanjangan baru.

Untuk lebih jelas hal ini dapat diketahui dari bunyi pasa 914 KUH Perdata yang pada pokoknya menyebutkan sebagai berikut:

1. Jika yang ditinggalkan hanya seorang anak, maka legitine portie anak itu adalah $1 / 2$ dari harta peninggalan.

7 Ibid., 120. Lihat juga Hilman Hadikusuma, Hukum Waris Adat (Bandung: PT. Citra Aditiya Bakti, 1993), 106.

${ }^{8}$ Wirjono Prodjodikoro, Hukum Warisan di Indonesia (Bandung: Sumur, 1983), 41.

${ }^{9}$ Ibid., 22. 
2. Jika yang ditinggalkan dua orang anak, maka legitine portie masingmasing anak adalah 2/3 dari bagian ab intestato masing-masing anak.

3. Jika yang ditinggalkan tiga orang anak atau lebih, maka bagian masing-masing anak adalah 3/4 dari bagian ab intestato masingmasing anak. ${ }^{10}$

Yang dimaksud dengan tiga orang anak atau lebih adalah termasuk pula semua keturunannya, akan tetapi statusnya sebagai pengganti. Inilah corak hukum waris di Indonesia saat ini yang masing-masing mempunyai karakter tersendiri, memiliki kelebihan dan kekurangan sesuai dengan alam pikiran dan jiwa pembentukannya, sehingga pluralitas pemikiran hukum waris di Indonesia menjadi suatu kelaziman.

Hukum kewarisan Islam yang diberlakukan di Indonesia tertuang dalam KHI yang berperan sebagai sumber hukum kewarisan di Peradilan Agama, namun produk pemikirannya belum sepenuhnya mampu memberi solusi yang memuaskan bagi komunitas Muslim di Indonesia, sehingga masih banyak pengaduan sengketa waris ke Pengadilan Negeri oleh masyarakat Muslim yang tidak puas dengan keputusan Pengadilan Agama.

KHI juga tidak selalu dipahami secara saksama oleh masyarakat Muslim Indonesia, terutama oleh tokoh agama Islam yang fanatik menerapkan hukum kewarisan Islam yang tertuang dalam kitab-kitab fiqh klasik, sehingga upaya merevisi KHI demi menyempurnakan aturan-aturan hukum Islam yang khas keindonesiaan mendapat banyak kritikan atau bahkan penegasian dari pihak-pihak yang hanya berpegang pada teks atau format hukum Islam yang telah dianggap mapan dan sakral, sehingga kodifikasi hukum Islam harus tetap seperti pemahaman pada masa Rasul dan sahabatnya.

Fiqh klasik yang menjadi referensi KHI bukan saja tidak relevan dari sudut materialnya, melainkan juga bermasalah dari kerangka paradigmanya. Misalnya, pendefinisian fiqh selalu dipahami sebagai "mengetahui hukum shara" yang bersifat praktis yang diperoleh dari dalil al-Qur'ân dan Sunnah". Jika mengacu pada definisi tersebut, kebenaran fiqh menjadi sangat normatif. Kebenaran fiqh bukan dimatriks dari seberapa jauh ia memberikan kemaslahatan bagi manusia, melainkan pada seberapa jauh ia benar dari aspek perujukannya pada aksara atau teks al-Qur'ân dan Sunnah.

${ }^{10}$ Ibid., 68. 
Dengan demikian, rekonstruksi hukum kewarisan Islam di Indonesia melalui paradigma universal al-Qur'ân-yang memuat prinsip kemaslahatan, keadilan, pluralisme, persamaan HAM, dan kesetaraan gender-menjadi sangat signifikan demi terealisasinya produk hukum yang berkeadilan, menjunjung nilai kemanusiaan, menghargai hak perempuan, meratanya nuansa kerahmatan, serta terwujudnya kemaslahatan bagi seluruh umat manusia, khususnya masyarakat Indonesia yang bersifat komunal.

Berdasar pada academic problem di atas, artikel ini berusaha menggali model penafsiran yang ditawarkan oleh Abdullah Saeed terhadap ayat-ayat waris dan korelasinya dengan hukum kewarisan di Indonesia dan sejauh mana teori Hirarki Nilai Abdullah Saeed bermanfaat bagi penerapan hukum kewarisan di Indonesia.

\section{Biografi Singkat Abdullah Saeed}

Abdullah Saeed, salah satu tokoh Muslim yang mendukung dan mengembangkan gagasan kontekstual yang melahirkan ijtihad progresif, adalah salah seorang ilmuwan Australia yang lahir pada 28 Januari 1960 di Maldives, sebuah pulau di Samudra Hindia yang kemudian membentuk diri menjadi negara Republik. Negara kecil ini terletak di bagian utara lautan India sekira $500 \mathrm{~km}$ atau $310 \mathrm{~km}$ Barat Daya India. Penduduk yang menghuni negara kecil tersebut berasal dari Srilanka, India, dan Arab. Bahasa yang digunakan adalah bahasa Divehi yang berasal dari Srilanka. Mayoritas penduduknya beragama Islam. $^{11}$

Perjalanan karir akademik Saeed dimulai pada tahun 1977, ia menempuh pendidikan di Arab Saudi, antara lain: di Institut Bahasa Arab Dasar (1977-1979), selanjutnya pada Institut Bahasa Arab Menengah (1979-1982), lalu pada Universitas Islam Saudi Arabia di Madinah (1982-1986), dengan gelar Bachelor of Arts dalam bahasa Arab dan Studi Islam. Dia menyandang gelar PhD dalam Studi Islam serta Master of Arts dalam bidang Linguistik Terapan dari Universitas Melbourne, yang diperoleh pada tahun 1992 dan 1994. Pada tahun 1993, ia diangkat sebagai asisten dosen pada jurusan Bahasa-bahasa Asia dan Antropologi di Universitas Melbourne. Pada tahun 1996 ia menjadi dosen senior, lalu pada tahun 2000 ia telah menjadi anggota

\footnotetext{
11 Ghufron Hamza, "Hermeneutika Abdullah Saeed dalam Interpreting the Al-Qur'ân: Toward Contemporary Approach" dalam Kurdi dkk, Hermeneutika Al-Qur'an dan Hadis (Yogyakarta: Penerbit el-SAQ Press, 2010), 205-206.
} 
asosiasi profesor, dan tiga tahun kemudian (2003) ia berhasil meraih gelar professor dalam bidang Studi Arab dan Islam.

Saat menulis buku Interpreting The Qur'ân: Toward Contemporary Approach (2006), Saeed menjabat sebagai Direktur Pusat Kajian Islam Kontemporer pada Universitas Melbourne, Australia. Saat ini Saeed menjabat sebagai direktur Asia Institute dan direktur National Centre of Excelence for Islamic Studies (NCEIS), Universitas Melbourne. Lembaga ini didirikan untuk mengembangkan studi-studi tentang Asia, baik itu dilihat dari sisi agama, budaya, bahasa, dan lain sebagainya, karena itu Lembaga tersebut memfasilitasi pengkajian tentang Asia (Asia Studies).

Karya tulis yang telah dihasilkan Saeed cukup banyak, di antaranya adalah: Islamic Banking and Interest (1996, 1999), Islam and Political Legitimacy (2003), Islam in Australia (2003), Freedom of Religion, Apostasy and Islam (co-author, 2004), "Fazlur Rahman: A Framework for Interpreting the Ethico-Legal Content of the al-Qur'ân" dalam Modern Muslim Intellectuals and the al-Qur'ân, Suha Taji-Farouki (ed.) (2004), "Riba" dalam Encyclopedia of Islam (2004), Approaches to alQur'ân in Contemporary Indonesia (2005) dan masih banyak lagi karyakarya Saeed, baik dalam bentuk buku, jurnal, maupun ensiklopedia.

Sebagai bagian ijtihad di era kontemporer, produk Islam progresif menurut Saeed berupaya merelasikan berbagai konteks kebutuhan masyarakat Muslim modern dalam memahami sumber otoritas Muslim demi menjaga semangat dan melestarikan karakter tradisi Islam", ${ }^{12}$ namun diseminasi ide Islam progresif, menurut Saeed, mengalami beberapa kendala, antara lain: adanya anggapan bahwa hanya ada satu paket hukum Islam yang dapat diterima sebagai kebenaran tunggal (truth claim). Pemahaman ini masih menguat di kalangan masyarakat Muslim. ${ }^{13}$ Oleh karena itu upaya reinterpretasi nasss-nass. hukum dan pembingkaian ulang metode penetapan hukum harus dilakukan demi menemukan kembali fleksibel dan elastisnya hukum Islam yang tidak hanya berkutat pada produk ijtihad masa lalu, tetapi produk ijtihad tersebut harus mempunyai semangat zaman hari ini. Proyek inilah yang sedang diperjuangkan oleh Saeed dalam buku Interpreting the al-Qur'an: Toward Contemporary Approach.

12 Ahmad Imam Mawardi, "Islam Progresif dan Ijtihad Progresif dalam Pandangan Abdullah Saeed" dalam Abdul Basith Junaidi et.al., Islam dalam Berbagai Pembacaan Kontemporer (Yogyakarta: Pustaka Pelajar, 2009), 528.

${ }^{13}$ Ibid., 529. 
Saeed memang sangat concern dengan dunia Islam kontemporer. Di dalam dirinya ada semangat menghidupkan spirit Islâm șaliḥ li kull zamân wa makân. ${ }^{14}$ Motto ini menjadi spirit Islam progresif, yang subjeknya dikenal dengan Muslim progresif. Karena itu ia berupaya mengaktifkan kembali dimensi progresif Islam yang selama ini telah tertekan oleh dominasi teks melalui berbagai pendekatan kontemporer yang mampu menghubungkan antara pertimbangan historis teks dan pertimbangan konteks kekinian, sehingga pesan al-Qur'ân tetap dapat hidup dan dapat diterapkan. Upaya inilah yang disebut dengan ijtihad progresif. $^{15}$

Salah satu pemikir yang dianggap mempengaruhi Saeed adalah Fazlur Rahman (w. 1988). Pemikiran Rahman tampaknya banyak mewarnai pikiran Saeed, di mana hal itu terlihat dari produk pemikiran Saeed tentang interpretasi al-Qur'ân yang kental dengan metode pendekatan kritik sejarah (socio-bistorical context). Menurut Saeed, Rahman melihat bahwa fiqh secara sosio-historis memiliki alam yang jauh berbeda dan selalu berkembang, sehingga harus ada penyegaran dan kontektualisasi dengan berbagai suasana dan kondisi geografis, budaya, politik, ekonomi dan sosial. ${ }^{16}$

Selain Fazlur Rahman, model dan gaya berpikir Saeed banyak juga diwarnai oleh metode pemikiran Ghulam Ahmad Parvez (w.1985), Mohammed Arkoun, Farid Esack, dan Khaled Abou El Fadl. Nama-nama di atas adalah representasi dari para pemikir rasionalis-modernis, yang bergerak dalam ijtihad progresif. Dalam pandangan mereka, kandungan etika-hukum dalam al-Qur'ân seharusnya diarahkan pada pemahaman kontekstual agar lebih aplikatif dalam merespons berbagai persoalan kontemporer yang muncul. ${ }^{17}$

\section{Genealogi Pemikiran Hermeneutika Abdullah Saeed}

Proyek Saeed dalam framework ijtihad progresifnya dapat ditelusuri antara lain: ${ }^{18}$ pertama, melalui gagasan hermeneutika double movement Fazlur Rahman. Teori interpretasi tersebut bekerja dalam pola dua gerakan ganda. Gerakan pertama berusaha memahami secara

\footnotetext{
${ }^{14}$ Saeed, Interpreting the Qur'ân, 2-3.

15 Ibid., 4-5. Baca juga Abdullah Saeed, Islamic Thought: An Introduction (London dan New York: Routledge, 2006), 55.

${ }^{16}$ Saeed, Interpreting the Qur'ân, 4.

${ }^{17}$ Ibid., 5-6.

${ }^{18}$ Ibid., 3-4, 6, 12, 127-128, 139,147.
} 
keseluruhan kandungan al-Qur'ân melalui perintah dan larangan yang diturunkan secara khusus sebagai respons terhadap situasi tertentu. ${ }^{19}$

Gerakan pertama (dari situasi kini ke masa al-Qur'ân turun) ini harus melalui dua tahap. Tahap pertama, melakukan pemahaman tekstual al-Qur'ân dan konteks sosio-historis ayat-ayatnya (task of understanding). Tahap ini mensyaratkan adanya pemahaman secara makro mengenai situasi kehidupan di Arab, baik dari sisi kehadiran Islam di Makkah, adat istiadat ataupun masyarakatnya. Tahap kedua, melakukan realisasi. Di tahap ini terdapat upaya untuk menerapkan prinsip dan nilai-nilai sistematik dan umum dalam konteks penafsiran pada era kontemporer sekarang. Untuk mempraktikan gerak kedua ini tentunya menyaratkan sebuah pemahaman yang kompleks terhadap suatu permasalahan. ${ }^{20} \mathrm{Di}$ sini Rahman menekankan pula pentingnya koreksi atas penafsiran pada pemahaman pertama. Jika pemahaman pada gerakan pertama gagal diaplikasikan pada pemahaman gerakan kedua, berarti telah terjadi kegagalan dalam menilai situasi masa kini atau kegagalan dalam memahami al-Qur'ân. ${ }^{21}$

Kedua, gagasan Ghulam Ahmad Parvez yang menganjurkan penggunaan metode "kembali kepada prinsip-prinsip" al-Qur'ân. ${ }^{22}$ Parvez berpendapat bahwa al-Qur'ân memuat semua prinsip yang diperlukan untuk menerapkan konsep keislaman tentang keyakinan dan amal saleh yang ditetapkan, baik oleh rasio maupun wahyu. Ia telah berusaha melakukan demitologisasi ${ }^{23}$ terhadap konsep-konsep

19 Ibid., 3-4. Baca juga Fazlur Rahman, Islam and Modernity: Transformation of an Intellectual Tradition, terj. Ahsin Mohammad (Bandung: Penerbit Pustaka, 1985), 7, 22 23.

${ }^{20}$ Ibid.

21 Ibid., 8-10, baca juga Farid Esack, Al-Qur'ân, Liberation, and Pluralism: An Islamic Perspective of Interrelegious SolidarityAgaints Oppression (England: One World, Oxford, 1997), 47. Teori Rahman tersebut memandang makna asal literal (bersifat historis) bukan sebagai pesan utama al-Qur'ân, karena itu ia hanya dijadikan sebagai pijakan awal bagi pembacaan al-Qur'ân di masa kini. Rahman menganjurkan agar pembaca (reader) masa kini berusaha memahami makna di balik pesan literal yang disebut ratio legis. Makna dibalik pesan literal inilah yang harus diimplementasikan pada masa kini dan akan datang. Sahiron Syamsuddin, Hermeneutika dan Pengembangan Ulumul AlQur'ân (Yogyakarta: Pesantren Nawasea Peress, 2009), 75. 22 Ibid., 6.

${ }^{23}$ Mempersepsikan mitos sebagai ungkapan simbolis mengenai satu realitas dengan mempergunakan gambaran-gambaran, kiasan-kiasan, dan lukisan-lukisan. Jadi yang dipermasalahkan di sini adalah bagaimana menafsirkan mitos secara eksistensial, bukan melenyapkannya. 
dalam al-Qur'ân yang dianggap bersifat mitos, ${ }^{24}$ sebagaimana telah dilakukan oleh M. Abduh dalam karyanya al-Mannâr, ketika menjelaskan Q.S. al-Baqarah [2]: 63 tentang menggantungnya Gunung Sinai (wa rafa'nâ fawqakum al-tûr) sebagai gempa bumi, penafsiran burung sebagai wabah pada Q.S. al-Fîl [105]: 3, dan sebagainya. Ini membuktikan apa yang terkandung dalam al-Qur'ân tidak bertentangan dengan alam. Karena itu mukjizat tidak harus dilihat sebagai mukjizat, tetapi sebagai fenomena yang mengikuti hukum alam. ${ }^{25}$

Menurut Saeed ada dua gagasan telah berkembang pada periode modern dalam mendukung kebutuhan pemahaman baru terhadap alQur'ân dalam waktu dan konteks yang berbeda, salah satunya adalah gagasan Parvez. Parvez menyatakan Islam memiliki esensi dan tidak pernah berubah, tetapi dalam aplikasinya mudah beradaptasi dan cair. Baginya, teks-teks yang diwahyukan tidak memiliki satu makna yang tetap, tetapi sebaliknya setiap generasi baru dapat berharap untuk mengeksplorasi makna baru dengan potensi mereka sendiri untuk memahami ajaran agama yang terus tumbuh. ${ }^{26}$

Gagasan yang kedua adalah bahwa petunjuk etbico-bukum alQur'ân dapat didekati pada dua tingkatan; pada tingkatan permukaan terkait dengan penerapan instruksi ethico-bukum tertentu; dan pada tingkatan lebih mendalam terkait dengan alasan yang mendasari instruksi tersebut. Alasan yang mendasari instruksi tersebut harus memastikan apakah penerapan instruksi literer tingkat permukaan harus diikuti dengan ketat di semua waktu, tempat, dan konteks. Jika alasan yang mendasari untuk penerapan instruksi ethico-bukum yang terkait dengan keadaan sosial, sejarah, ekonomi, politik tertentu atau lainnya tidak ada lagi, maka penerapan instruksi etbico-bukum dapat 'ditangguhkan' atau 'diam'. Jika keadaan berubah lagi, penerapan ethicobukum dapat diberlakukan kembali.

Inspirasi pemikiran Saeed ketiga adalah gagasan Mohammed Arkoun melalui gagasan dekonstruksi wahyu. ${ }^{27}$ Gagasan tersebut dapat dipahami dengan membaca kronologi wahyu dan aktan-aktan, ${ }^{28}$ yang

24 Fahruddin Faiz, Hermeneutika al-Qur'an: Tema-tema Kontroversial (Yogyakarta: Penerbit el-SAQ Press, 2005), 14.

${ }^{25}$ Saeed, Interpreting the Qur'ân, 13-14.

26 Ibid., 21.

${ }^{27}$ Ibid., 6.

28 Salah satu unsur linguistik, yaitu pelaku yang melakukan tindakan yang berada dalam teks atau narasi. 
terlibat dalam proses turun ayat (tangîl). Dalam proses tersebut, ada empat fase yang dilalui wahyu: fase kalam Allah, fase wacana Qur'âni, fase korpus resmi tertutup (closed official corpus), dan fase korpus tertafsir (interpreted corpus).

Fase wacana al-Qur'ân merupakan tahap paling kaya dan belum mengalami pembangunan sistem dogma oleh para yuris-teolog, karena itu Arkoun ingin menggapai kembali tahapan tersebut. Ia berpendapat bahwa transformasi ujaran ${ }^{29}$ ke dalam teks sangat terkait dengan kepentingan kekuasaan. Meski Arkoun menyadari bahwa tahap tersebut sudah hilang dan tidak mungkin direka kembali, namun ia berharap dapat menemukannya dalam karya-karya klasik tentang proses pengumpulan teks ayat-ayat al-Qur'ân. ${ }^{30}$

Pada fase korpus resmi tertutup, wahyu menurut Arkoun menjelma sebagai fakta budaya (tahap semio-linguistik) yang berada dalam tataran sejarah dan budaya manusia. Ia memiliki tiga implikasi dasar, antara lain: 1) Wacana al-Qur'ân yang bersifat lisan ditransformasikan menjadi teks; 2). Sifat suci teks meluas kepada wadah fisiknya, yaitu buku tempat wacana al-Qur'ân dituliskan; dan 3). Buku sebagai instrumen budaya menjadi dasar perubahan sosial. ${ }^{31}$

Fase korpus tertafsir dikaitkan oleh Arkoun dengan produktivitas teks, bukan wacana. Jadi, menurut Arkoun, tradisi keagamaan dihasilkan dari penafsiran teks tertulis, bukan penafsiran terhadap wacana al-Qur'ân. Dalam konteks inilah terjadi penggandaan semantis, simbolis, dan ideologis atas teks dalam ruang sejarah sosial, politik, dan kebudayaan. ${ }^{32}$

Rekonstruksi pembabakan turunnya wahyu sampai kepada audiens oleh Arkoun merupakan upaya untuk menilai kembali klaimklaim ortodoksi yang merasa sebagai penafsir al-Qur'ân paling sah. Melalui rekonstruksi tersebut, Arkoun juga ingin memberikan porsi pendekatan antropologis dan semiotis kepada wahyu sebelum ia

\footnotetext{
29 Dalam pengertian linguistik dapat dipandang sebagai suatu hubungan antara berbagai aktan yang membentuknya.

30 Mohammed Arkoun, Lecture du Coran, terj. Machasin (Jakarta: INIS, 1997), 7.

31 Mohammed Arkoun, "Gagasan tentang Wahyu: Dari Ahl al-Kitab sampai Masyarakat Kitab" dalam HLM Chambert Loir dan NJG (ed.) Islam di Perancis: Gambaran Pertama (Jakarta: INIS, 1992), 47.

32 Arkoun, Lecture du, 6.
} 
dipahami oleh para ulama dan menjadi cabang-cabang keilmuan Islam. $^{33}$

Upaya tersebut kemudian mengantar Arkoun kepada sikap dekonstruksi terhadap pembacaan al-Qur'ân yang selama ini dianggap mapan. Dekonstruksi menurutnya memungkinkan pembacaan yang cair terhadap teks tanpa terjebak dalam oposisi biner; benar versus salah, Islam versus kufur, mukmin versus mulhid, maupun tauhid versus musyrik. Padahal dalam kenyataan kehidupan manusia terlalu kompleks untuk direduksi secara sederhana ke dalam dua posisi bipolar tersebut. ${ }^{34}$

Pembongkaran kembali proses-proses sebelum pembakuan teks dan wacana keagamaan melalui historisisme akan menggiring pada pengenalan dan kritik teks, juga meliputi usaha transformasi muatan teks yang diproduksi dalam episteme dominan (oleh ortodoksi). Maka upaya Arkoun melawan logosentrisme (tektualisme) merupakan sebuah konsekuensi dari pandangan bahwa bahasa al-Qur'ân adalah bahasa mitis dan pesan agama tidak bersifat tunggal, melainkan dapat dibaca dari ragam perspektif. Penegasian terhadap status bahasa mitis akan menghilangkan kekayaan kandungan al-Qur'ân. ${ }^{35}$

Mitos merupakan bagian dari angan-angan sosial. Ia dibentuk oleh proyeksi nilai yang diambil dari sejarah nyata, realitas masyarakat, dan lingkungan fisik. Keseluruhan pemaknaan dalam angan-angan sosial disampaikan dalam kisah lisan yang dilafalkan melalui metafora, simbol, dan mitos. Kenangan yang dihasilkan, menurut Arkoun, mengakarkan kelompok dalam suatu sejarah bermakna, mendasar, mendalam, yaitu menguasai jiwa kelompok dalam waktu yang panjang. ${ }^{36}$ Karena itu, menurut Saeed, penggunaan analisis kritis dengan metode-metode kontemporer menjadi jalan untuk membebaskan masyarakat Muslim dari belenggu logosentrisme agar tidak mengabaikan angan-angan sosial tersebut. ${ }^{37}$

33 Tholhatul Choir, "Mohammed Arkoun dan Dekonstruksi Ortodoksi" dalam Abdul Basith Junaidi et.al., Islam dalam Berbagai Pembacaan Kontemporer et.al., Islam dalam Berbagai Pembacaan Kontemporer (Yogyakarta: Pustaka Pelajar, 2009), 107.

${ }^{34}$ Saeed, Interpreting the Qur'an, 6.

35 Mohammed Arkoun, Nalar Islam dan Nalar Modern: Berbagai Tantangan dan Jalan Baru, terj. Rahayu. S (Jakarta: INIS, 1994), 70.

36 Mohammed Arkoun, Târikhîyat al-Fiker al-Arabî al-Islâmî (Beirut: Markaz al-Inmâ' al-Qawmî, 1986), 66.

${ }^{37}$ Saeed, Interpreting the Qur'ân, 6. 
Inspirasi pemikiran Saeed keempat adalah gagasan Farid Esack melalui pendekatan hermeneutika pembebasan. Teori tersebut didasarkan atas pembacaan teks terhadap realitas praksis. Ketika realitas tersebut harus diubah karena terjadi ketimpangan, maka harus dicarikan justifikasinya dari ayat-ayat, karena semangat teks sesunguhnya adalah pembebasan dari ketimpangan. Ayat-ayat dimaknai secara baru untuk mendukung gagasan dan upayanya dalam memberikan perubahan sosial masyarakat sesuai dengan élan vital alQur'ân sendiri. ${ }^{38}$

Perspektif dasar yang dibangun oleh Esack dalam hermeneutikanya menekankan sebuah penafsiran yang bersifat partikular, kontekstual, dan relevansi praksis dari sebuah teks. Karena setiap pengalaman non-profetik manusia pada dasarnya bersifat interpretatif dan selalu diperantarai oleh konteks budaya dan personalitas yang tak tertransendensi, sehingga tidak mungkin tercipta sebuah penafsiran tunggal, universal, statis, dan bebas nilai. Sebaliknya kondisi di atas justru meniscayakan setiap penafsiran yang akan selalu bersifat kontekstual-partikular, temporer, dan bias. ${ }^{39}$

Pandangan tersebut mengacu pada pola hubungan yang terjadi secara dialektis antara proses pewahyuan, bahasa, substansi teks dengan lokus-tempus audiens yang menerimanya. Pandangan ini menurut Esack, melahirkan "kaca pandang" baru pada proses pewahyuan al-Qur'ân yang disebut dengan "pewahyuan progresif" Berdasarkan pandangan ini, maka pada dasarnya sebuah teks kitab suci selalu hadir dan menyapa umatnya dalam konteks partikular (terbatas secara linguistik, geografis, situasional, dan kontekstual) atau dalam istilah tradisi klasik dikenal dengan asbâb an-nuqûl dan naskh wa mansûk $b^{41}$

Metode hermeneutika Esack terdiri dari dua prosedur teknis, prosedur regresif dan prosedur progresif. Prosedur regresif melihat kembali ke masa lalu secara kontinyu bukan hanya untuk memperhitungkan kebutuhan-kebutuhan dan keinginan-keinginan masa kini atas teks, tetapi juga untuk mengungkap mekanisme historis dan

\footnotetext{
38 Esack, al-Qur'ân, 63.

39 Farid Esack, "Contemporary Religious Thought in South Africa and the Emergence of al-Qur'ân Hermeneutical Notion" dalam I.C.M.R.2 (1991), 222-223 baca juga The al-Qur'ân: A User's Guide (England: Oneworld Oxford, 2005), 145. Saeed, Interpreting the Qur'ân, 6, 26, 34.

${ }^{40}$ Saeed, Interpreting the Qur'ân, 34. Baca Esack, al-Qur'ân, 54.

${ }^{41}$ Ibid.
} 
faktor-faktor yang memproduksi teks-teks ini dan memberikan fungsi tertentu terhadapnya. ${ }^{42}$ Prosedur progresif bergerak dalam rangka menghidupkan makna baru sebagaimana tuntutan konteks pada masa kini. Oleh karena itu, yang harus dilakukan dalam prosedur ini adalah memeriksa secara cermat proses transformasi muatan-muatan dan fungsi-fungsi awal ke dalam muatan dan fungsi baru. ${ }^{43}$ Metode inilah yang digarisbawahi oleh Saeed dalam membangun teori Hirarki Nilainya. ${ }^{44}$

Inspirasi pemikiran Saeed kelima adalah gagasan Khaled Abou El Fadl melalui teori hermeneutika negosiatif. Gagasan El Fadl bertujuan menghindari sikap otoriter, dan menjaga kesadaran bahwa teks (alQur'ân) memiliki hak dan integritasnya sendiri. Al-Qur'ân merupakan "karya yang terus berubah" atau "wahyu progresif", sehingga segala bentuk penafsiran dan pemahaman akan terus aktif, dinamis, dan progresif. ${ }^{45}$

Hermeneutika negosiatif El Fadl tidak hanya mencoba menemukan makna teks, tetapi juga untuk menyingkap kepentingan penggagas atau pembaca yang tersimpan di balik teks, dan menawarkan strategi pengendalian tindakan despotis pembaca teks, pembaca lain, dan audiens. ${ }^{46}$ Hermeneutika negosiatif tersebut berpijak dari prinsip "negosiasi" kreatif antara teks-penggagas-pembaca, ${ }^{47}$ dengan menjadikan teks sebagai titik pusat yang bersifat terbuka. ${ }^{48}$ Ketika sebuah pemikiran lepas dari penggagas dan telah diwujudkan ke dalam bentuk teks tertulis, maka teks itu mengalami otonomi relatif rangkap tiga, antara lain: otonom dari penggagas, otonom dari makna awal, dan otonom dari audiensi awal. Meski demikian, pesan penggagas masih tersimpan dalam teks, sehingga pesan itu masih dapat dilacak melalui pembacaan yang bersifat negosiasi antara penggagas, teks, dan pembaca. $^{49}$

\footnotetext{
${ }^{42}$ Esack, "Contemporary, 218-219.

43 Ibid.

${ }^{44}$ Saeed, Interpreting the Qur'an, 6, 26, dan 34.

${ }^{45}$ Khaled Abou El Fadl, Atas Nama Tuban: Dari Fikih Otoriter ke Fikih Otoritatif, terj.

R. Cecep Lukman Yasin (Jakarta: Serambi, 2002), 372.

46 Ibid., 90.

47 Ibid..

${ }^{48}$ Ibid., 373. Nasr Hamid Abu Zaid, al-Qur'ân, Hermeneutika, dan Kekuasaan, terj. Dede Iswadi (Bandung: RqiS, 2003), 75-80.

${ }^{49}$ Ibid., 373.
} 
Menurut Saeed, kontribusi El Fadl itu terletak pada konten ethicobukum. Ide-ide El Fadl tentang otoritas, komunitas interpretif dan perannya dalam menghasilkan makna, dan keseimbangan antara teks, author, dan pembaca, serta kritis tapi hati-hati untuk pendekatan Hadîth, merupakan kontribusi yang besar dalam perdebatan tentang penafsiran al-Qur'ân dan hukum dalam konteks Islam saat ini. ${ }^{50}$

Gagasan hermeneutika mulai Rahman yang bercorak objektif, Parvez, Arkoun, serta Esack yang bersifat subjektif, sampai hermeneutika El Fadl yang bersifat negosiatif telah mendukung bangunan hermeneutika demokratis-kontekstual Saeed. Titik temu gagasan mereka terletak pada ide tentang hak teks (wahyu tertulis) dan hak pembaca teks yang selama ini terabaikan, terlupakan, dan mendorong tindakan "mengunci" pesan wahyu (Tuhan) dalam sebuah penetapan makna tertentu yang bersifat absolut, final, dan konklusif.

Demi menjaga hak masing-masing teks dan pembaca, maka pemahaman terhadap al-Qur'ân menurut Saeed harus melibatkan seluruh metodologi tafsir yang ada secara holistik, baik tradisi penafsiran tekstualis klasik-modern, maupun kontekstualis klasikmodern demi menemukan spirit dan pesan moral al-Qur'ân, untuk kemudian direalisir demi menjawab problem-problem kekinian. ${ }^{51}$

\section{Teori Hirarki Nilai Abdullah Saeed}

\section{A. Konsep Pewahyuan Menurut Abdullah Saeed}

Ayat-ayat al-Qur'ân menurut Saeed, seharusnya dipahami bukan hanya secara parsial tetapi juga secara universal, sehingga objek esensinya semakin luas dan mampu memecahkan berbagai persoalan komtemporer yang muncul. Saeed juga berpendapat, bahwa produktivitas dan kreativitas para ulama salaf dalam menghasilkan karya-karya monumental saat itu adalah sebagai bukti, bahwa interpretasi al-Qur'ân bukan hanya otoritas ulama klasik, akan tetapi ulama kontemporer dan siapa saja yang mampu memberikan interpretasi, memiliki otoritas sama, sehingga tidak ada istilah pintu ijtihat tertutup. ${ }^{52}$

Saeed melihat bahwa reinterpretasi melalui pendekatan sosiohistoris (kritik sejarah) akan menempatkan fungsi fundamental alQur'ân sebagai raḥmah li al-âlamîn di mana fleksibilitasnya akan selalu

\footnotetext{
${ }^{50}$ Saeed, Interpreting the Qur'ân, 6, 25.

51 Ibid., 5.

52 Ibid., 22.
} 
relevan dengan perkembangan ilmu pengetahuan. ${ }^{53}$ Proses pewahyuan menurut Saeed memberikan penjelasan tentang terjadinya hubungan yang erat antara wahyu dan kepribadian keagamaan Nabi Muhammad. Ada tiga cara komunikasi Tuhan dengan Nabi Muhammad, antara lain melalui wahyu, di balik hijab, dan mengirim utusan untuk menyampaikan pesan-Nya. Cara pewahyuan tersebut sebagaimana penjelasan Q.S. al-Shûrâ [42]: $51 .{ }^{54}$

Cara pertama: berupa waby, yaitu jenis komunikasi langsung dari Tuhan kepada seseorang yang dituju, tanpa suara dan tanpa seorang utusan. Seseorang yang menerimanya "memahami" bahwa itu berasal dari Tuhan. ${ }^{55}$

Cara kedua: penyampaikan pesan di balik hajjâb, dalam arti Allah berfirman kepada seseorang tanpa pendengar itu melihat Yang (Allah) berbicara, karena pada dasarnya Allah adalah invisible $e^{56}$ sebagaimana jenis komunikasi Allah dengan Nabi Musa dalam penjelasan Q.S. alQașaș [28]: $30 .^{57}$

Cara ketiga: penyampaian pesan "melalui seorang utusan". Jenis inilah yang dipegangi oleh para teolog Muslim, bahwa pembawa pesan (al-Qur'ân) tersebut adalah Malaikat Jibril dengan menggunakan bahasa Arab. ${ }^{58}$ Beberapa ayat menjelaskan bahwa ketika Muhammad "mendengar" pesan, beliau berusaha memahami dan mencoba mengulangi kata-kata dalam rangka mengingatnya. ${ }^{59}$

Wahyu dalam kategori ketiga menurut Izutsu berarti menyatakan diri melalui bahasa. ${ }^{60}$ Jadi pengalaman yang terpenting dari proses pewahyuan Nabi Muhammad adalah pengalaman pada apa yang "difirmankan Tuhan", bukan yang lain. ${ }^{61}$ Konteks wahyu itu objektif, tidak subjektif. Objektivitas ini dibangun melalui fakta bahwa pesan itu diberikan dalam bahasa sendiri. Pengalaman dari "melihat" perantara (malaikat) dan "mendengar" suara pada waktu, dan memahami "apa yang dikatakan" (seperti yang dilaporkan dalam Hadîth) semua

\footnotetext{
${ }^{53}$ Ibid.

${ }^{54}$ Ibid., 31.

55 Ibid.

${ }^{56}$ Q.S. al-An'âm [6]: 103.

${ }^{57}$ Saeed, Interpreting the Qur'an., 31-32.

${ }^{58}$ Q.S. al-Shu'arâ' [26]: 192-195.

${ }^{59}$ Q.S. al-Qiyâmah [75]: 16-19. Ibid., 32-33.

${ }^{60}$ Saeed, Interpreting the Qur'ân, 33.

${ }^{61}$ Ibid., 37.
} 
menunjukkan realitas objektif isi wahyu. ${ }^{62}$ Al-Qur'ân dengan demikian setara dengan wahyu verbal yang diberikan kepada Nabi. ${ }^{63}$

Menurut Saeed, terdapat empat proses wahyu dengan mempertimbangkan konteks sosial-historis, antara lain: ${ }^{64}$

Tingkat pertama: ketika berada pada lawḩ mahfü berada pada tingkat mistri (ghayb) dan metode transmisi tidak banyak diketahui karena berada di luar pengalaman manusia. ${ }^{65}$

Tingkat kedua: wahyu berada pada konteks "spirit eksternalisasi pikiran dan hati Nabi", di mana wahyu dikomunikasikan melalui R $\mathrm{h} h$ (yang dikenal dengan Jibril) ke dalam hati Nabi Muhammad dalam bahasa Arab, yaitu bahasa Nabi Muhammad dan masyarakatnya. Tahap ini wahyu berada dalam bentuk fisik yang dapat dipahami oleh manusia. Karena itu wahyu pada tahap ini sangat dipengaruhi oleh problem-problem masyarakat Arab pada saat itu, sehingga ia menjadi pesan yang khusus bagi Nabi dan masyarakatnya. Meski demikian, tidak jarang Nabi dan masyarakatnya juga menerima pesan yang bersifat universal. ${ }^{66}$

Tingkat ketiga: berbentuk teks yang melebar kepada konteks teks. Ketika wahyu telah berbentuk teks (lisan maupun tulisan), maka ia sangat erat dengan konteks komunitas Nabi. Teks inilah yang kemudian diriwayatkan, dikomunikasikan, diajarkan, dijelaskan dan diaktualisasikan. Kehadiran dan keterlibatan Nabi di dalam komunitas dan wahyu, dapat menambah eksistensi teks, serta meningkatkan volume dari aktualitas teks kepada komunitasnya sebagaimana pengayaan makna yang diperoleh, baik dari sisi pemahaman, maupun dari sisi praksis terhadap teks tersebut. ${ }^{67}$

Tingkat keempat: wahyu berada pada tahap interpretasi teks tertutup yang memungkinkan adanya komunikasi inspirasi konteks. Penutupan interpretasi teks akibat wafatnya Nabi tidak berarti bahwa aspek-aspek tertentu dari wahyu (non-kenabian, non-linguistik, dan non-tekstual) sudah tidak lagi ada. ${ }^{68}$

Dua aspek kewahyuan terus berlanjut. Pertama, praksis, yang dipandu oleh wahyu diawali dengan Nabi dan masyarakatnya, yang

${ }^{62}$ Ibid., 38.

${ }^{63}$ Ibid.

${ }^{64}$ Ibid., 39.

${ }^{65}$ Ibid., 39-40.

${ }^{66}$ Ibid., 40.

${ }^{67}$ Ibid.

${ }^{68}$ Ibid., 41. 
terus ditularkan kepada masyarakat berikutnya. Setiap masyarakat pada gilirannya menambah khazanah pemahaman; yang terus-menerus memperluas pemahaman; dan yang kian bergerak menjauh dari Nabi dan komunitasnya. ${ }^{69}$

Kedua, bimbingan ilahi terus diberikan oleh Allah kepada orangorang yang selalu sadar akan bimbingan tersebut, dan terus-menerus berusaha untuk menjaga komunitas mereka dan mereka sendiri di jalan Allah. Kuantitas ini merupakan sebuah bentuk 'inspirasi' yang terus berlangsung, aspek ini termasuk non-kenabian dan non-linguistik. ${ }^{70}$

Dalam pemahaman wahyu, konteks sosio-historis wahyu adalah elemen mendasar yang tidak lepas dari instrumen manusia, yaitu peran Nabi yang juga tidak terlepas dari masyarakatnya. Hubungan yang mendasar tentang wahyu tersebut tetap bahkan setelah ketidakhadiran Nabi, dan terus mempertahankan hubungan melalui komunitas praksis dan interpretif. ${ }^{71}$

\section{B. Sistem Hirarki Nilai dalam Penafsiran Ayat Waris}

Kontribusi pemikiran Saeed yang paling penting dalam proyek penafsiran kontekstualnya adalah penyusunan Hirarki Nilai dalam upaya menyempurnakan ideal moral yang digagas Fazlur Rahman. Hal itu dilakukan demi membangun pemahaman baru untuk pembacaan al-Qur'ân pada masa kini dan yang mampu diterapkan masyarakat Muslim dalam merespons kearifan lokal masing-masing.

Hirarki Nilai tersebut adalah nilai-nilai yang bersifat wajib (obligatory values), nilai-nilai fundamental (fundamental values), nilai-nilai proteksional (protectional values), nilai-nilai implementasional (implementational values), dan nilai-nilai instruksional (instructional values). ${ }^{72}$

Nilai-nilai yang bersifat wajib memiliki nilai tetap, tidak akan berubah (immutable), dan berpotensi menjadi doktrin agama yang abadi. Ayat-ayat ethico-legal yang masuk kategori ini antara lain: ayat-ayat yang membangun sistem kepercayaan (rukun iman), praktik ibadah, dan ayat-ayat yang berkaitan dengan masalah halal dan haram. ${ }^{73}$

Nilai-nilai fundamental merupakan nilai-nilai tertentu yang berhubungan dengan hak asasi manusia yang tercakup dalam lima nilai universal (uşul al-khamsah): yaitu hak hidup, hak kepemilikan, hak

\footnotetext{
${ }^{69}$ Ibid.

${ }^{70}$ Ibid.

${ }^{71}$ Ibid.

72 Ibid., 129-130.

73 Ibid., 130-131.
} 
kehormatan, hak keluarga, dan hak agama. Nilai etis yang berada dalam level ini bersifat dinamis, sesuai dengan kebutuhan masyarakat. ${ }^{74}$

Nilai-nilai proteksional berfungsi untuk menjaga keberlangsungan nilai-nilai fundamental, misalnya ayat yang melarang membunuh, melarang mencuri, melarang berzina, melarang minum khamr, melarang pemaksaan memeluk agama tertentu dan lain sebagainya, maka larangan tersebut memiliki nilai proktesional. ${ }^{75}$

Sedangkan nilai-nilai implementasional adalah tindakan atau ukuran spesifik yang digunakan untuk melaksanakan nilai-nilai proteksional. Nilai ini dapat menerima perubahan (mutable) dan mungkin berbeda menurut konteks yang menyertainya. Nilai dalam level ini berdasarkan konteks kultural dan bisa berubah. Aturan tersebut bukanlah objek fundamental al-Qur'ân, melainkan pada tujuan (maqậid)-nya sebagai pencegahan terhadap perilaku yang tidak diharapkan. Misalnya hukum potong tangan pada zaman awal Islam mungkin relevan, tetapi tidak relevan untuk saat kini. ${ }^{76}$

Adapun yang terakhir nilai-nilai instruksional merupakan ukuran atau tindakan yang terdapat dalam teks ayat al-Qur'ân tentang sebuah persoalan yang berlaku khusus pada masa pewahyuan. ${ }^{77}$ Ayat al-Qur'ân yang berada dalam level ini sangat banyak dan variatif. Misalnya, instruksi poligami, instruksi menjadikan pria sebagai penjaga perempuan, instruksi untuk tidak menjadikan non-Muslim sebagai teman. Relevansi nilai etis yang berada dalam level ini seringkali dipertanyakan dalam kehidupan kontemporer. ${ }^{78}$ Oleh karena itu, Saeed mengenalkan tiga kriteria untuk menentukan makna legal-etis teks yang berada dalam level ini, yaitu: frekuensi penyebutannya dalam al-Qur'ân, salience (urgensitas atau penekanan nilainya pada periode Nabi), dan relevansinya dengan memperhatikan konteks kultural pada masa pewahyuan dan mengidentifikasi apakah nilai tersebut merupakan nilai objektif atau hanya sekadar pendukung terhadap tercapainya nilai yang lebih fundamental. ${ }^{79}$

Langkah-langkah yang harus dilakukan oleh para pembaca alQur'ân, selain mengenali Hirarki Nilai-nilai tersebut di atas demi menghadirkan konteks historis ke dalam pemahaman al-Qur'ân pada

\footnotetext{
${ }^{74}$ Ibid., 132-134.

75 Ibid., 134.

76 Ibid., 134-136.

${ }^{77}$ Ibid., 137-138.

78 Ibid., 137.

${ }^{79}$ Ibid., 139-141.
} 
masa kini, maka framework penafsiran kontekstual al-Qur'ân yang digagas oleh Saeed adalah sebagai berikut: ${ }^{80}$

1. Tahap pertama, pengenalan teks dan dunianya secara lebih luas dan umum (konteks historis), menelusuri sabab nuəûul.

2. Tahap kedua, kritik analisis dengan membiarkan teks itu berkata tentang dirinya sendiri, baik kepada masyarakat penerima pertama, atau sampai sekarang, melalui eksplorasi beberapa aspek teks:

a. Linguistik: arti kata, frase dan arti secara gramatikal (tata bahasa).

b. Konteks Literal: apa sebab turun dan bagaimana seharusnya ayat tersebut dipahami.

c. Bentuk Literal: identifikasi permasalahan, apakah tentang hukum, sejarah, ibadah atau lainnya.

d. Teks Paralel: identifikasi apakah ada ayat lain yang memiliki kesamaan.

e. Preseden: identifikasi apakah ada ayat yang memiliki kesamaan konten tetapi berbeda maksud dan tujuan.

3. Tahap ketiga, kaitan teks dengan konteks awal penerimaan alQur'ân.

a. Analisis kontekstual: kondisi sejarah dan sosial termasuk di dalamnya kondisi budaya, keyakinan, norma, dan sistem nilai yang melingkupi.

b. Menentukan klasifikasi ayat apakah tentang hukum, teologi atau etika (akhlak).

c. Menentukan objek kajian yang lebih dominan.

d. Evaluasi bagaimana teks itu diterima, dipahami dan dipraktikkan oleh masyarakat kala itu.

4. Tahap keempat, kaitan teks dengan konteks masa kini

a. Analisis konteks masa kini.

b. Konteks masa kini versus konteks sosio-historis.

c. Pemahaman teks sejak masa awal penerimaan sampai masa kini.

d. Risalah: kontekstual versus universal.

e. Aplikasi untuk hari ini.

${ }^{80}$ Ibid., 150-152. 


\section{Framework Penafsiran Kontekstual Abdullah Saeed}

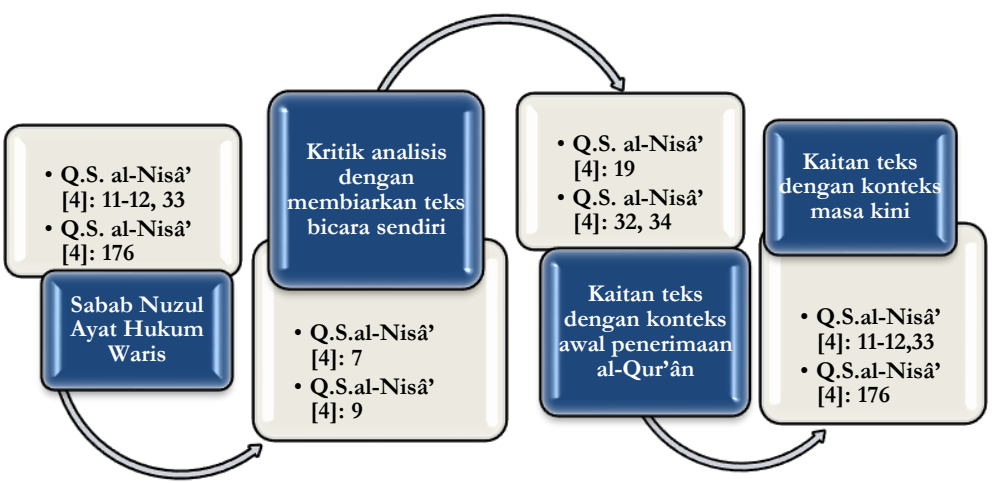

Berdasarkan prosedur standar operasional penafsiran yang ditawarkan oleh Saeed di atas, maka masalah buudûd, warisan, pernikahan dan lain sebagainya, yang selama ini dipahami sebagai hukum yang harus dilaksanakan secara legal, juga harus dibangun di atas nilai moral yang menyertai esensi konstruksi hukumnya, sehingga budûd, warisan, pernikahan dalam Islam yang dibangun dari nilai-nilai khusus instruksional (instructional values) ayat-ayat ethico-legal, dapat dipertimbangkan lagi berdasarkan keempat nilai-nilai yang lain: yaitu ketetapan nilai yang bersifat wajib (obligatory values), nilai fundamental (fundamental values) yang mendasari bangunan hukum, nilai proteksional (protectional values) yang berfungsi menjaga eksistensi nilai fundamental, dan nilai implementasional (implementational values) yang dapat berubah sesuai perubahan kebutuhan masyarakat Muslim.

Hirarki Nilai yang ditawarkan oleh Saeed dalam merespon sistem pembagian waris adat di Indonesia dapat diilustrasikan sebagai berikut:

Aplikasi Sistem Nilai dalam Penafsiran Q.S. al-Nisâ' [4]: 11

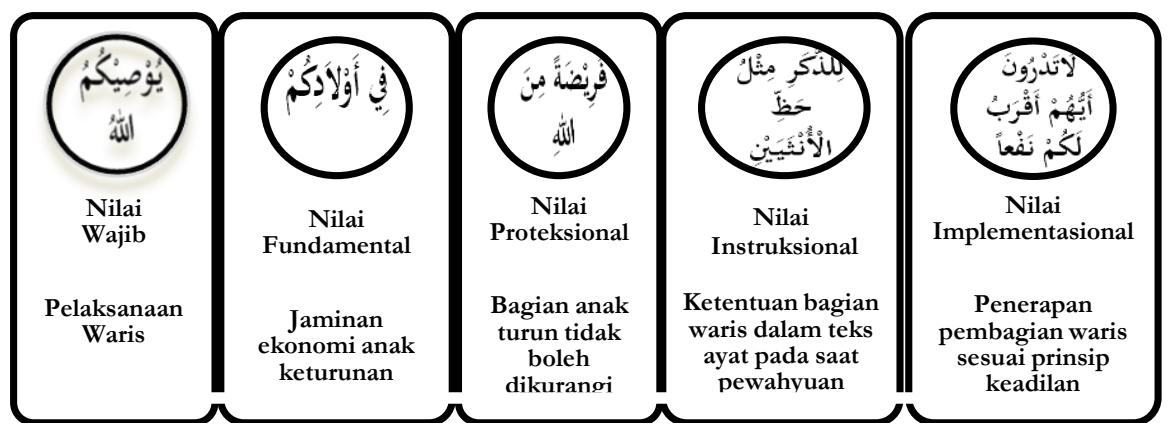

Aplikasi dari teori Hirarki Nilai salah satunya digunakan untuk menafsirkan ayat kewarisan. Teks Q.S. al-Nisâ' [4]: 11 dianggap sebagai 
ajaran universal yang selalu berfungsi di segala zaman dan tempat. Ia memiliki nilai fundamental (fundamental values) hak properti dan jaminan ekonomi bagi anak turun pewaris, dan nilai proteksionalnya adalah menyangkut ketentuan bagian waris bagi anak turun pewaris. Sedangkan nilai instruksinya yang khusus dalam ayat adalah li al-dhakar mithl haza al-unthayayn. Adapun nilai implementasionalnya boleh diganti sesuai dengan perkembangan kebutuhan masyarakat Muslim dalam menerapkan prinsip keadilan, sehingga pembagian 1:2 boleh disesuaikan untuk konteks masa kini dengan pertimbangan peran perempuan yang sudah mengalami perubahan, tidak seperti eksistensi-nya pada masa teks itu dibangun dan diinstruksikan.

\section{Isu Pembagian Waris di Indonesia}

Dasar hukum waris yang berlaku di Indonesia merujuk pada tiga sumber hukum: Hukum Waris Adat, Hukum Waris Islam, dan Hukum Waris Perdata. Setiap daerah memiliki hukum yang berbeda-beda sesuai dengan sistem kekerabatan yang dianut.

Berdasarkan Surat Mahkamah Agung RI tanggal 8 Mei 1991 No. MA/kumdil/171/V/K/1991 ditetapkan ketentuan kewenangan hukum berdasarkan masing-masing kelompok penduduk di Indonesia yaitu:

1. Penduduk asli Indonesia, berlaku hukum adat;

2. Orang Belanda, Eropa dan yang dipersamakan dengan itu berlaku hukum perdata (BW);

3. Keturunan Tiongkok sejak tahun 1919 berlaku Hukum Perdata Barat;

4. Keturunan Timur Asing Lainnya (Arab, Hindu, Pakistan dan lainlain) dalam pewarisan berlaku hukum negara leluhurnya.

Sejak terbitnya Instruksi Presiden Republik Indonesia Nomor 1 Tahun 1991 tanggal 10 Juni 1991 yang dilaksanakan melalui Keputusan Menteri Agama Nomor 154 tanggal 22 Juli 1991, maka posisi KHI menjadi sumber hukum dalam masalah pewarisan bagi penduduk Indonesia yang beragama Islam. Adapun lembaga pengawas atas pewarisan tersebut adalah Peradilan Agama.

Pengadilan agama berwenang mengeluarkan fatwa atau penetapan mengenai pembagian harta peninggalan seorang pewaris yang beragama Islam. Kewenangan ini berdasarkan ketentuan pasal 49 huruf b UU No. 3/2006 tentang perubahan atas UU No. 7/1989 tentang peradilan agama. Fatwa waris dikeluarkan oleh Pengadilan Agama atas dasar permohonan ahli waris. Fatwa waris berlaku sebagai 
keterangan siapa saja (ahli waris) yang berhak untuk mewarisi harta peninggalan pewaris. Berdasarkan fatwa waris tersebut, maka notaris/PPAT dapat menentukan siapa saja yang berhak untuk menjual tanah warisan dimaksud.

Pada tataran aplikasinya, cukup banyak warga non-Muslim di Indonesia lebih memilih dan memakai hukum waris yang diatur dalam KUHPerdata daripada hukum waris yang ditentukan sesuai dengan isi fatwa waris Mahkamah Agung. Upaya ini sering disebut dengan "penundukan secara sukarela" dan diperbolehkan berdasarkan pasal 131 ayat (2) huruf b yang menjelaskan bahwa:

Untuk orang-orang Indonesia, golongan Timur Asing atau bagianbagian dari golongan-golongan itu, yang merupakan dua golongan dari penduduk sepanjang kebutuhan masyarakat menghendaki, diberlakukan baik ketentuan perundang-undangan untuk golongan Eropa, sedapat mungkin dengan mengadakan perubahan seperlunya, maupun ketentuan perundang-undangan yang sama dengan golongan Eropa. Sedangkan untuk hal-hal lain yang belum diatur, bagi mereka berlaku peraturan hukum yang bertalian dengan agama dan adat-kebiasaan mereka. Yang hanya dapat menyimpang dari itu, apabila ternyata kepentingan umum atau kebutuhan masyarakat menghendakinya.

Dengan adanya fasilitas penundukan secara sukarela ini, sebagian besar penduduk Indonesia yang beragama selain Islam melaksanakan kegiatan pewarisannya berdasarkan KUHPerdata. Oleh karena kecenderungan seperti itu, banyak yang berspekulasi bahwa hukum kewarisan di Indonesia yang berlaku hanya dua, yaitu Hukum Kewarisan Islam berdasarkan KHI dan UU No. 3/ 2006 untuk penduduk Indonesia yang beragama Islam dan Hukum Kewarisan Perdata Barat berdasarkan KUHPerdata untuk penduduk non-Muslim di Indonesia. Meskipun dalam praktiknya terjadi demikian, namun hal itu tidak mengubah keberlakukan Hukum Adat dan Hukum Agama masing-masing dari penduduk non-Muslim untuk diterapkan.

Hukum Perdata Barat yang terdapat dalam KUHPerdata bersifat mengatur atau anvullenrecht. Hal ini bermaksud bahwa sebenarnya tidak ada unsur paksaan dalam menerapkan ketentuan yang terdapat dalam KUHPerdata untuk menyelesaikan permasalahan kewarisan di Indonesia.

Ketiga sistem hukum waris tersebut memiliki karakteristik dan ciri khas masing-masing yang mengakibatkan terjadinya perbedaan antara yang satu dengan lainnya. Namun demikian apabila berbicara persoalan hukum waris, problem itu tidak terlepas dari tiga unsur 
pokok antara lain: adanya harta peninggalan atau kekayaan pewaris yang disebut warisan, adanya pewaris yaitu orang yang menguasai atau memiliki harta warisan, dan adanya ahli waris yaitu orang yang menerima pengalihan harta warisan.

Keunikan hukum waris bangsa Indonesia terletak pada fenomena kewarisan yang tidak harus melalui peristiwa kematian seseorang yang meninggalkan harta benda, di mana ahli waris kemudian dapat membagi dan dapat memiliki harta peninggalan secara bebas, tetapi seringkali kewarisan terjadi dalam arti penunjukan atau penerusan harta kekayaan pewaris sejak pewaris masih hidup.

Untuk bidang hukum waris adat misalnya, pluralitas kewarisan itu terjadi disebabkan adanya pola susunan kekeluargaan atau kekerabatan yang dianut di Indonesia. Adapun susunan tersebut antara lain:

1. Pertalian keturunan menurut garis laki-laki (patrilineal). Misalnya berlaku pada masyarakat Batak, Bali, dan Ambon.

2. Pertalian keturuman menrut garis perempuan (matrilineal), berlaku pada masyarakat Minangkabau, Kerinci (Jambi), Semendo (Sumetera Selatan).

3. Pertalian keturunan menurut garis ibu dan bapak (Parental/Bilateral). Misalnya berlaku di dalam masyarakat Melayu, Bugis, Jawa, Kalimantan (Dayak), dan lain-lain.

Di samping itu dalam hal sistem pewarisan terbagi atas tiga pola, antara lain:

1. Sistem pewarisan individual yang diterapkan pada susunan kekeluargaan bilateral (Jawa) dan susunan kekeluargaan patrilineal (Batak).

2. Sistem pewarisan kolektif yang diterapkan pada harta pusaka tinggi di Minangkabau, dan Ambon.

3. Sistem pewarisan mayorat yang diterapkan pada sistem pewarisan di Bali, Lampung, dan lain-lain.

Hukum waris adat di Indonesia pada masyarakat parental atau bilateral tidak mengenal cara pembagian waris dengan perhitungan matematika (angka), tetapi selalu didasarkan pada pertimbangan wujud banda dan kebutuhan ahli waris. Jadi walau hukum waris adat mengenal prinsip kesamaan hak, tidak berarti setiap ahli waris akan mendapat bagian warisan dalam jumlah yang sama, dengan nilai harga yang sama atau menurut banyaknya bagian yang sudah ditentukan.

Tata cara pembagian waris adat itu ada dua kemungkinan, yaitu: a). Dengan cara segendong sepikul. Artinya, bagian anak lelaki dua kali 
lipat bagian anak perempuan; dan b). Dengan cara dum-dum kupat. Artinya, bagian waris anak lelaki dan bagian anak perempuan sama. ${ }^{81}$

Pembagian waris yang banyak diberlakukan adalah pembagian berimbang sama di antara semua anak. Demikianlah karakteristik budaya kewarisan Indonesia yang berbeda dengan pola hukum Islam. Pembagian tersebut dilatari oleh budaya bangsa Indonesia yang dengan falsafah Pancasila bisa hidup bersama, rukun, selaras, dan damai. ${ }^{82}$

Hukum waris adat di Indonesia merupakan potret masyarakat Indonesia. Hukum adat mempunyai sifat dan corak berbeda dari hukum Eropa Barat yang individualistis-liberal. Corak hukum adat mempunyai perbedaan sebagai berikut: ${ }^{83}$

1. Mempunyai sifat kebersamaan (communaal) yang kuat. Artinya, manusia menurut hukum adat merupakan makhluk dalam ikatan kemasyarakatan dan kebersamaan yang erat.

2. Mempunyai corak magisch-religieus yang berhubungan dengan pandangan hidup alam Indonesia.

3. Sistem hukum itu diliputi oleh pikiran-pikiran serba konkret. Artinya, hukum adat sangat memperhatikan banyaknya dan berulang-ulangnya perhubungan hidup yang konkret. Misalnya bagaimana keadaan teman-teman di masyarakat, perhubungan jual (pemindahan) pada perjanjian tentang tanah, dan sebagainya.

4. Hukum adat mempunyai sifat yang sangat visual. Artinya, perhubungan-perhubungan hukum dianggap hanya terjadi oleh karena ditetapkan dengan suatu ikatan yang dapat dilihat. Hukum adat sebagai hukum tak tertulis dibentuk dan diselenggarakan oleh putusan-putusan dari penyelenggara hukum dalam masyarakat, yaitu pertama-tama para hakim dalam tata hukum gubernemen "Hindia Belanda" dan dalam tata-hukum daerah-daerah swapraja dan selanjutnya para kepala desa dalam lapisan bawah yang luas dari masyarakat desa. ${ }^{84}$

Sebagai bagian dari hukum adat, sifat dan corak tersebut dapat dilihat dalam hukum waris adat. Sifat komunal dapat dilihat dari sifat harta waris. Harta waris dalam hukum adat tidak merupakan kesatuan yang abstrak yang dapat dinilai dengan uang atau jika mungkin dibagi atau dijual kemudian hasilnya dibagikan kepada ahli warisnya, tetapi

\footnotetext{
${ }^{81}$ Hadikusuma, Hukum Waris Adat, 106.

82 Basyir, Hukum Waris Islam, 126.

${ }^{83}$ B. Ter Haar, Asas-asas dan Susunan Hukum Adat (t.t.: Pradnya Paramita, 1980).

${ }^{84}$ R. Soepomo, Hukum Adat (Jakarta: Pradnya Paramita, 1987), 107.
} 
harta waris dalam hukum adat merupakan suatu kesatuan yang bersifat konkret yang tidak dapat dibagi.

Menurut hukum waris adat, peninggalan tidak merupakan satu kesatuan dengan harta waris yang bukan harta peninggalan dari pewaris. Karena itu harus dilihat asal-usul, sifat, dan kedudukan dari harta dalam hubungannya dengan pewaris. Sesuai dengan aliran pikiran bangsa Indonesia sebagaimana tersebut di atas, dalam hukum waris adat terdapat sifat-sifat khas sesuai dengan falsafah Pancasila bangsa Indonesia. Dengan uraian yang berpangkal dari sila-sila Pancasila sebagai pandangan hidup bangsa Indonesia, maka dapat disimpulkan bahwa di dalam hukum waris adat bangsa Indonesia bukan sematamata terdapat asas kerukunan dan asas kesamaan hak dalam pewarisan, tetapi terdapat juga asas-asas hukum yang terdiri dari: 1). Asas ketuhanan dan pengendalian diri; 2). Asas kesamaan hak dan kebersamaan hak; 3) Asas kerukunan dan kekeluargaan; 4) Asas musyawarah dan mufakat; dan 5) Asas keadilan dan parimirma.

Upaya unifikasi hukum melalui legalitas KHI dalam bentuk Instruksi Presiden kepada Menteri Agama pada tanggal 22 Juli 1991 mempertegas posisi hukum Islam sebagai salah satu sumber hukum di Indonesia selain KUHPerdata (BW) dan hukum adat. KHI merupakan produk fiqh Indonesia, karena ia disusun dengan memperhatikan kondisi kebutuhan hukum umat Islam Indonesia. Penegakan Hukum Islam dideskripsikan dengan realisasi KHI.

Pembentukan KHI merupakan penjabaran dari pasal 49 Undangundang No. 7 Tahun 1989 tentang peradilan Agama. Pasal 49 memerlukan kodifikasi dan unifikasi hukum yang memadai untuk mewujudkan kesadaran masyarakat mengenai pelaksanaan hukum Islam di bidang perkawinan, kewarisan, wasiat, hibah, sedekah, dan wakaf. Oleh karena itu, penyusunan KHI diresmikan melalui yurisprudensi dalam keputusan bersama Ketua Mahkamah Agung RI dan Menteri Agama RI No. 07/KMA/1985 dan No. 25 Tahun 1985 tanggal 25 Maret 1985. Kemudian pada tahun 2006 diperluas lagi dengan Pasal 49 Undang-Undang No. 3 Tahun 2006 tentang kewenangan Peradilan Agama dalam pelaksanaan bidang perkawinan, kewarisan, wasiat, hibah, wakaf, zakat, infak, sedekah, dan ekonomi sharî‘'ah.

KHI disusun dan dirumuskan dalam kitab hukum sebagai tata hukum Islam yang berbentuk positif dan unifikatif. Semua lapisan masyarakat Islam dipaksa tunduk menaatinya. Pelaksanaan dan 
penerapannya tidak lagi diserahkan atas kehendak pemeluknya, tetapi ditunjuk Lembaga Peradilan Agama sebagai aparat pengawas dan pelaksanaan penerapannya. Dengan adanya peran PA sebagai aparat yang mengawasi pelaksanaannya, sepanjang hal-hal yang menyangkut bidang perkawinan, kewarisan, wasiat, hibah, wakaf, zakat, infak, sedekah, dan ekonomi sharî́'ah, maka ia menjadi aturan yang menyangkut ketertiban umum.

KHI juga memuat asas-asas hukum waris Islam berkarakter Indonesia antara lain: asas $i j b a ̂ r \hat{r}$, asas bilateral, asas individual, dan asas keadilan.

Asas ijbârî secara umum terlihat pada ketentuan umum mengenai perumusan pengertian kewarisan, pewaris, dan ahli waris. Secara khusus, asas ijbârî mengenai cara peralihan harta warisan juga disebut dalam ketentuan umum tersebut dan pada pasal 187 ayat 2 yang berbunyi "sisa pengeluaran dimaksud di atas adalah merupakan harta warisan yang harus dibagikan kepada ahli waris yang berhak". Perkataan 'harus' dalam pasal ini menunjukkan asas ijbârî. Tentang bagian masing-masing' ahli waris dinyatakan dalam Bab III Pasal 176 sampai dengan Pasal 182. Mengenai siapa yang menjadi ahli waris disebutkan dalam Bab II, Pasal 174 ayat 1 dan $2 .{ }^{85}$

Asas bilateral dapat dibaca pada pengelompokan ahli waris seperti tercantum dalam pasal 174 ayat (1) yaitu ayah, anak laki-laki, saudara laki-laki, paman dan kakek (golongan laki-laki); serta ibu, anak perempuan, saudara perempuan dan nenek (golongan perempuan) menurut hubungan darah. Penyebutan secara tegas golongan laki-laki dan perempuan serempak menjadi ahli waris dalam pasal tersebut memperjelas asas bilateral. Duda atau janda menjadi ahli waris berdasarkan hubungan perkawinan adalah juga ciri kewarisan bilateral dalam KHI. ${ }^{86}$

Asas individual juga tercermin dalam pasal-pasal mengenai besarnya bagian ahli waris dalam KHI, Bab III pasal 176 sampai dengan pasal 180. Khusus bagi ahli waris yang memperoleh harta warisan sebelum ia dewasa atau tidak mampu bertindak melaksanakan hak dan kewajibannya atas harta yang diperolehnya dari kewarisan,

85 Tim Penulis, Kompilasi Hukum Islam: Buku II (Yogyakarta: Pustaka Widyatama, 2004), 82 .

${ }^{86}$ Ibid. 
baginya diangkat wali berdasarkan putusan hakim atas usul anggota keluarganya sebagaimana diatur dalam pasal $184 \mathrm{KHI} .^{87}$

Asas keadilan berimbang dalam KHI terutama terdapat dalam pasal-pasal mengenai besarnya bagian yang disebut dalam pasal 176 dan pasal 180. Juga diproyeksikan penyesuaian perolehan yang dilakukan pada waktu penyelesaian pembagian warisan melalui (1) pemecahan secara awl dengan membebankan kekurangan harta yang akan dibagi kepada semua ahli waris yang berhak menurut kadar bagian masing-masing. Hal ini disebut dalam pasal 192 dengan menaikkan angka penyebut sesuai atau sama dengan angka pembilangnya. Selain itu agar asas keadilan berimbang, hal itu dapat diwujudkan waktu penyelesaian pembagian warisan. (2) pemecahan secara radd, yakni mengembalikan kelebihan harta kepada ahli waris yang ada sesuai dengan kadar bagian masing-masing. Dalam hubungan ini perlu ditekankan bahwa terdapat perbedaan pendapat mengenai siapa yang berhak menerima pengembalian itu. Namun, mayoritas ulama mengatakan bahwa yang berhak menerima pengembalian sisa harta itu hanya ahli waris karena hubungan darah, bukan ahli waris karena hubungan perkawinan.

Dengan kelahiran KHI sebagi hukum positif dan unifikatif, maka praktik private affairs disingkirkan. Sejak KHI lahir, dimulai sejarah baru di Indonesia, yang memposisikan penerapan hukum Islam sebagai hukum perdata yang resmi dan dapat dipaksakan penerapannya oleh aparatur negara, terutama oleh Lembaga Peradilan Agama. Adanya penyeragaman paham yang menempatkan hukum Islam yang diatur dalam KHI sebagai hukum perdata yang resmi dan positif, yang memiliki sanksi dan dapat dipaksakan oleh aparatur negara, masih terasa berat.

Paradigma unifikasi hukum pada ranah keluarga terlihat secara nyata diterapkan negara pada kasus KHI. Penyeragaman sistem hukum ini absah saja dilakukan asalkan memenuhi prinsip keadilan gender dan pluralisme beragama. Tapi kenyataan di lapangan seringkali berkata lain. Banyak produk fiqh yang direkrut dalam KHI justru bersifat diskriminatif terhadap perempuan dan tidak memiliki semangat proteksi terhadap kepentingan anak-anak.

\section{Teori Hirarki Nilai dan Hukum Kewarisan di Indonesia}

Sampai saat ini posisi KHI semenjak terbitnya Instruksi Presiden Nomor 1 Tahun 1991 tertanggal 10 Juni 1991 dan dilaksanakan

${ }^{87}$ Ibid., 84. 
melalui Surat Keputusan Menteri Agama Nomor 154 tanggal 22 Juli 1991 merupakan sumber dan pedoman hukum Islam bagi masyarakat Muslim Indonesia, termasuk hukum kewarisan.

Terdapat pembaruan yang cukup menonjol dalam KHI, terutama jika dibandingkan dengan sistem kewarisan yang dikembangkan oleh kelompok Sunnî (yang menonjolkan sistem 'asabab) maupun kelompok Shî'ah (yang menonjolkan sistem dhû al-qarâbah). Cerminan asas bilateral dalam KHI adalah pasal 174 ayat 2 yang berbunyi: Apabila semua abli waris ada, maka yang berbak mendapat warisan hanya anak, ayah, $i b u$, janda atau duda. ${ }^{88}$ Kalimat pendek dalam pasal ini mengakhiri polemik panjang tentang apakah anak perempuan dapat menghalangi saudara pewaris atau tidak.

Selain pasal tersebut ada beberapa pasal yang memberikan tempat bagi sistem kewarisan adat antara lain:

Pasal $183 \mathrm{KHI}$ mempertimbangkan asas kewarisan adat yaitu asas musyawarah dan mufakat demi menjaga asas kerukunan dan kekeluargaan bila pembagian waris dalam KHI kurang memenuhi asas keadilan dan asas kesamaan hak dan kebersamaan hak.

Pasal $185 \mathrm{KHI}$ juga mengakomodir hak waris pengganti yang dikenal dalam kewarisan adat dengan menyebutkan hak dari ahli waris pengganti apabila ahli waris asal sudah meninggal lebih dulu daripada pewaris.

1. Ahli waris yang meninggal lebih dahulu dari pewaris, maka kedudukannya dpat digantikan oleh anaknya, kecuali mereka yang tersebut dalam Pasal 173.

2. Bagian Ahli Waris Pengganti tidak boleh melebihi dari bagian ahli waris yang sederajat dengan yang diganti.

KHI juga mengakomodir sistem pembagian kewarisan adat dalam Pasal 189 KHI yang membenarkan adanya kewarisan kolektif atas harta waris yang tidak mungkin dibagi, karena bila dibagi akan mengurangi nilai dan kualitas harta waris.

KHI juga memberikan jaminan kewarisan disebabkan adanya hubungan dalam status sosial, baik bersifat ubûwah, dan bunûwah dalam Pasal 209 KHI pada ayat 1 dan 2 yang mengatur hak saling mewarisi antara anak angkat dan orang tua angkat.

Namun ditilik dari segi isi, menurut Siti Musdah Mulia, KHI dinilai sangat konservatif. Dilihat dari aspek kesetaraan gender, banyak sekali pasal yang tidak sesuai dengan aspirasi keadilan gender.

88 Tim Penulis, Kompilasi, 82. 
Misalnya, pasal kewajiban suami-istri, pembagian harta kekayaan, dan hak perwalian. Karena itu, menurut Musdah, hampir semua pasal yang ada mengandung persoalan, maka perlu ada reformasi atas butir-butir KHI ini. ${ }^{89}$

Dinamika lahirnya KHI mestinya memberikan pemikiran baru demi menyempurnakan isi KHI yang sejalan dengan alam pikiran masyarakat Indonesia. Utamanya bila mempertimbangkan asas kewarisan Islam dan asas kewarisan adat masyarakat Indonesia. Dalam posisi ini kontribusi penerapan teori Hirarki Nilai Abdullah Saeed dalam meresponw hukum kewarisan adat yang selama ini mengenal pembagian waris dum-dum kupat bisa diterapkan untuk memenuhi keadilan dan kesetaraan gender serta pluralitas keberagamaan, di samping semangat proteksi terhadap kepentingan anak-anak.

Nilai instruksi saat ayat waris turun merupakan dasar nilai implementasional saat kini harus sejalan dengan tujuan hukum kewarisan (maqâsid al-irth) yang menjadi prinsip dasar dalam penetapan hukum waris. Karena efektivitas sistem hukum kewarisan itu diukur berdasarkan pada pemenuhan tujuannya (maqâsid), yakni menjamin kelangsungan kehidupan anak keturunan dan orang tua pewaris dalam bingkai prinsip keadilan.

Sejalan dengan analisis Hirarki Nilai yang ditawarkan oleh Saeed, sistem pembagian waris dum-dum kupat di kalangan masyarakat bilateral atau parental, yang didasarkan pada asas keadilan serta asas kesamaan hak dan kebersamaan hak di samping asas kerukunan dan kekeluargaan, perlu diakomodir dalam KHI.

Berdasarkan nilai implementasional yang dibangun Saeed, maka sistem pembagian 1:1 sebagaimana yang terjadi di kalangan masyarakat parental Jawa dan tempat lain yang menerapkan sistem pembagian kewarisan adat dum-dum kupat bisa dibenarkan. Ketentuan ini berpeluang merevisi pasal 176 pada Bab III KHI yang mengatur tentang besarnya bagian warisan. Meski penerapannya bisa dilakukan dengan cara musyawarah untuk menghasilkan kesepakatan yang damai sebagaimana dalam KHI pasal 183 yang mengakomodir asas musyawarah dan mufakat dalam kewarisan adat.

\section{Penutup}

89 Siti Musdah Mulia, "Counter Legal Draf Kompilasi Hukum Islam: Upaya Implementasi CEDAW dalam Perkawinan”, Jurnal Perempuan: Sejaub Mana Komitmen Negara?, edisi 45, 2006. 
Teori Hirarki Nilai Abdullah Saeed dikonstruksi dalam upaya memberi ruang fleksibel dan elastis pada penerapan makna ayat-ayat hukum. Di sisi yang berbeda teori Hirarki Nilai dibangun demi menjaga prinsip agama yang kekal dan sakral. Teori tersebut memuat nilai-nilai yang bersifat wajib (obligatory values), nilai-nilai fundamental (fundamental values), nilai-nilai proteksional (protectional values), nilai-nilai instruksional (instructional values), dan nilai-nilai implementasional (implementational values).

Berdasarkan teori Hirarki Nilai Abdullah Saeed, maka isu kewarisan adat dum-dum kupat, yakni bagian waris anak lelaki sama dengan bagian waris anak perempuan bisa dibenarkan.

\section{Daftar Rujukan}

Arkoun, Mohammed. "Gagasan tentang Wahyu: Dari Ahl al-Kitab sampai Masyarakat Kitab" dalam HLM Chambert Loir dan NJG (ed.) Islam di Perancis: Gambaran Pertama. Jakarta: INIS, 1992.

-----. Lecture du Coran, terj. Machasin. Jakarta: INIS, 1997.

----- Nalar Islam dan Nalar Modern: Berbagai Tantangan dan Jalan Baru, terj. Rahayu. S. Jakarta: INIS, 1994.

----. Târikhîyat al-Fiker al-Arabî al-Islâmî. Beirut: Markaz al-Inmâ' alQawmî, 1986.

Basyir, Ahmad Azhar. Hukum Waris Islam. Yogyakarta: UII Press, 2001.

Choir, Tholhatul. "Mohammed Arkoun dan Dekonstruksi Ortodoksi" dalam Abdul Basith Junaidi et.al., Islam dalam Berbagai Pembacaan Kontemporer et.al., Islam dalam Berbagai Pembacaan Kontemporer. Yogyakarta: Pustaka Pelajar, 2009.

El Fadl, Khaled Abou. Atas Nama Tuban: Dari Fikih Otoriter ke Fikih Otoritatif, terj. R. Cecep Lukman Yasin. Jakarta: Serambi, 2002.

Esack, Farid. "Contemporary Religious Thought in South Africa and the Emergence of al-Qur'ân Hermeneutical Notion" dalam I.C.M.R.2, 1991.

-----. Al-Qur'ân, Liberation, and Pluralism: An Islamic Perspective of Interrelegious SolidarityAgaints Oppression. England: One World, Oxford, 1997.

Faiz, Fahruddin. Hermeneutika al-Qur'an: Tema-tema Kontroversial. Yogyakarta: Penerbit el-SAQ Press, 2005.

Haar, B. Ter. Asas-asas dan Susunan Hukum Adat. t.t.: Pradnya Paramita, 1980. 
Hadikusuma, Hilman. Hukum Waris Adat. Bandung: PT. Citra Aditiya Bakti, 1993.

Hamza, Ghufron. "Hermeneutika Abdullah Saeed dalam Interpreting the Al-Qur'ân: Toward Contemporary Approach" dalam Kurdi dkk, Hermeneutika Al-Qur'an dan Hadis. Yogyakarta: Penerbit el-SAQ Press, 2010.

Mawardi, Ahmad Imam. "Islam Progresif dan Ijtihad Progresif dalam Pandangan Abdullah Saeed" dalam Abdul Basith Junaidi et.al., Islam dalam Berbagai Pembacaan Kontemporer. Yogyakarta: Pustaka Pelajar, 2009.

Mulia, Siti Musdah. "Counter Legal Draf Kompilasi Hukum Islam: Upaya Implementasi CEDAW dalam Perkawinan", Jurnal Perempuan: Sejaub Mana Komitmen Negara?, edisi 45, 2006.

Penulis, Tim. Kompilasi Hukum Islam: Buku II. Yogyakarta: Pustaka Widyatama, 2004.

Prodjodikoro, Wirjono. Hukum Warisan di Indonesia. Bandung: Sumur, 1983.

Rahman, Fatchur. Ilmu Waris. Bandung: Penerbit al-Maarif, Cet. Ke-2, 1982.

Rahman, Fazlur. Islam and Modernity: Transformation of an Intellectual Tradition, terj. Ahsin Mohammad. Bandung: Penerbit Pustaka, 1985.

Saeed, Abdullah. Islamic Thought: An Introduction. London dan New York: Routledge, 2006.

Soepomo, R. Hukum Adat. Jakarta: Pradnya Paramita, 1987.

Syamsuddin, Sahiron. Hermeneutika dan Pengembangan Ulumul Al-Qur'ân. Yogyakarta: Pesantren Nawasea Peress, 2009.

Zaid, Nasr Hamid Abu. al-Qur'ân, Hermenentika, dan Kekuasaan, terj. Dede Iswadi. Bandung: RqiS, 2003. 